\title{
Spirochaeta thermophila sp. nov., an Obligately Anaerobic, Polysaccharolytic, Extremely Thermophilic Bacterium
}

\author{
HELENA YU AKSENOVA, ${ }^{1}$ FREDERICK A. RAINEY, ${ }^{2}+*$ PETER H. JANSSEN ${ }^{2}$ \\ GEORGE A. ZAVARZIN, ${ }^{1}$ AND HUGH W. MORGAN ${ }^{2}$ \\ Institute of Microbiology, USSR Academy of Sciences, Moscow, USSR, ${ }^{1}$ and Thermophile \\ and Microbial Biochemistry and Biotechnology Unit, University of \\ Waikato, Hamilton, New Zealand ${ }^{2}$
}

\begin{abstract}
Growth at temperatures of $>60^{\circ} \mathrm{C}$ and utilization of polysaccharides have not been reported previously in members of the genus Spirochaeta. Two obligately anaerobic, extremely thermophilic (optimum temperature, $65^{\circ} \mathrm{C}$ ) spirochetes were isolated from geographically distant thermal sites. These two isolates have chemoorganotrophic fermentative metabolism and grow on a variety of mono-, di-, and polysaccharides, including cellulose. The differences in $\mathrm{pH}$ and $\mathrm{NaCl}$ concentration optima between these organisms reflect the prevailing conditions at the sites from which they were isolated. DNA-DNA hybridization showed that the two strains exhibit a level of homology of $87 \%$. On the basis of their morphological characteristics, their high level of homology with each other, and their extremely thermophilic and polysaccharolytic nature, we propose that these organisms should be included in the genus Spirochaeta as a new species, Spirochaeta thermophila; the type strain of this species is strain Z-1203 (= DSM 6578).
\end{abstract}

The spirochetes belonging to the genus Spirochaeta include both obligately and facultatively anaerobic free-living forms which have been isolated from a variety of aquatic springs, including thermal springs (9-11). Recently, an obligately anaerobic, polysaccharolytic, extremely thermophilic spirochete, Spirochaeta sp. strain RI 19.B1, was isolated from a brackish $(0.76 \% \mathrm{NaCl})$ hot spring having a neutral $\mathrm{pH}$ on Raoul Island, Kermadec Archipelago, New Zealand. The characteristics of this organism have been described previously (10). A similar organism, strain $\mathrm{Z}-1203^{\mathrm{T}}$ ( $\mathrm{T}=$ type strain), was isolated from a marine hot spring on the beach of Shiashkotan Island, Kuril Islands, Kamchatka, USSR (11). In this paper we characterize these two strains and designate strain Z-1203 the type strain of a new species, Spirochaeta thermophila.

\section{MATERIALS AND METHODS}

Strains. Strains RI 19.B1 (= DSM 6192) (10) and Z-1203 (= DSM $6578^{\mathrm{T}}$ ) (11) were obtained from our culture collections in New Zealand and the USSR, respectively. The isolates described by Patel et al. (9) did not survive long-term storage and could not be used in this study.

Culture methods. Strain RI 19.B1 was grown on bicarbonate-buffered medium CBM4 as described previously (10). Strain Z-1203 ${ }^{\mathbf{T}}$ was grown on bicarbonate-buffered medium CBM15, which had the same composition as medium CBM4 except that the $\mathrm{NaCl}$ and $\mathrm{MgCl}_{2} \cdot 6 \mathrm{H}_{2} \mathrm{O}$ concentrations were raised to 15 and $2 \mathrm{~g} /$ liter, respectively.

Growth on amorphous cellulose as a sole carbon source was determined by adding $5 \mathrm{~g}$ of amorphous cellulose per liter to medium CBM15. Amorphous cellulose was prepared by adding $25 \mathrm{~g}$ of Avicel to $1,000 \mathrm{ml}$ of $5 \mathrm{M} \mathrm{ZnCl}_{2}$, and this suspension was added to $4,000 \mathrm{ml}$ of vigorously stirred distilled water. The resulting white flocculent was recovered by centrifugation at $8,000 \mathrm{rpm}$ for $20 \mathrm{~min}$. The combined

\footnotetext{
* Corresponding author.

$\dagger$ Present address: Department of Microbiology, The University of Queensland, Queensland 4072, Australia.
}

pellets were washed three times with distilled water and suspended overnight in $1,500 \mathrm{ml}$ of $25 \mathrm{mM}$ disodium EDTA. The flocculent was centrifuged again and washed four times with distilled water. The washed amorphous cellulose was stored as a slurry at $4^{\circ} \mathrm{C}$.

Analytical techniques. The physiological and metabolic properties, antibiotic susceptibilities, and DNA base compositions were determined as previously described (10). The level of DNA-DNA homology between the two strains was calculated from data obtained from optical reassociation kinetics by using the methods of DeLey et al. (4).

\section{RESULTS AND DISCUSSION}

Thermophilic spirochete strains. Strains RI 19.B1 and $\mathrm{Z}-1203^{\mathrm{T}}$ were isolated and characterized previously in two separate studies $(10,11)$. The salient characteristics of these two strains and strain Rt3-BS1, which was described by Patel et al. (9), are shown in Table 1. The morphology of strains RI 19.B1 and Z-1203 ${ }^{\mathrm{T}}$, together with their free-living nature and obligately anaerobic metabolism, places them in the genus Spirochaeta. These two strains have guanine-pluscytosine ratios of $52 \mathrm{~mol} \%$; their level of homology as determined by DNA-DNA hybridization is $87 \%$. We propose that these two strains represent a new species, Spirochaeta thermophila, with strain Z-1203 (= DSM 6578) as the type strain.

Morphological characteristics. The helical cells of both strains exhibited regular coiling (Fig. 1). Spherical bodies and tails similar to those observed in other spirochetes $(1$, 10) were present in the stationary phase. Electron microscopy revealed morphological features similar to those observed in other spirochetes $(5,6)$, including two periplasmic flagella and a central coiled protoplasmic cylinder, both of which were surrounded by a crenulated outer sheath. The periplasmic flagella were present in a 1-2-1 arrangement and were subterminally anchored by insertion discs. Thus, the two strains had morphological properties consistent with the properties of members of the order Spirochaetales $(2,3)$.

Nutritional characteristics. Both strains utilized a wide range of monosaccharides, disaccharides, and polysaccha- 
TABLE 1. Characteristics of three strains of thermophilic spirochetes

\begin{tabular}{|c|c|c|c|c|c|c|c|c|}
\hline Strain & Cell size $(\mu \mathrm{m})$ & $\begin{array}{c}\text { Temp range } \\
\text { (temp optimum) } \\
\left({ }^{\circ} \mathrm{C}\right)\end{array}$ & $\begin{array}{c}\mathrm{NaCl} \text { range } \\
(\mathrm{NaCl} \\
\text { optimum) } \\
(\%)\end{array}$ & $\begin{array}{c}\text { pH range } \\
\text { (pH optimum) }\end{array}$ & $\begin{array}{c}\text { Ethanol } \\
\text { produced } \\
\text { from glucose }\end{array}$ & $\begin{array}{c}\text { Strepto- } \\
\text { mycin MIC } \\
(\mu \mathrm{g} / \mathrm{ml})\end{array}$ & $\begin{array}{c}\mathrm{G}+\mathrm{C} \\
\text { content } \\
(\mathrm{mol} \%)\end{array}$ & Source \\
\hline $\mathrm{Z}-1203^{\mathrm{T}}$ & $0.2-0.25$ by $16-20$ & $40-73(66-68)$ & $0.5-4.5(1.5)$ & $5.9-7.7(7.5)$ & - & $>100$ & 52 & Marine hot spring \\
\hline RI 19.B1 & 0.2 by $10-50$ & $44-73(64-66)$ & $0.1-2.5(0.4)$ & $6.2-7.1(6.9)$ & - & $>100$ & 52 & Brackish hot spring \\
\hline $\mathrm{Rt} 3-\mathrm{BS} 1^{a}$ & $0.15-0.2$ by $15-25$ & $20-<60(45-50)$ & $\mathrm{ND}^{b}$ & $6.0-8.0(7.0-7.5)$ & + & $<10$ & ND & Freshwater hot spring \\
\hline
\end{tabular}

${ }^{a}$ Data from reference 9.

${ }^{b} \mathrm{ND}$, not determined.

rides as energy sources; these included D-amygdalin, L-arabinose, cellobiose, D-fructose, D-galactose, D-glucose, maltose, D-mannose, sucrose, D-xylose, amorphous cellulose, microcrystalline cellulose (Avicel), glycogen, pullulan, starch, and xylan. Substrates that were not utilized included erythritol, glycerol, inositol, lactose, D-mannitol, melezitose, melibiose, D-raffinose, L-rhamnose, D-ribose, D-sorbitol, L-sorbose, acetoin, trisodium citrate, sodium formate, disodium fumarate, disodium DL-malate, sodium pyruvate, disodium succinate, L-arginine, sodium L-glutamate, and L-lysine. Growth did not occur via the reduction of fumarate, nitrate, oxygen, sulfate, or sulfur. Indole was not formed from L-tryptophan. Urea was not hydrolyzed, nor was sulfide produced from L-cysteine. Esculin was hydrolyzed.

Glucose was fermented to acetate, carbon dioxide, hydrogen, and lactate. Strain Z-1203 ${ }^{\mathrm{T}}$ also produced isobutyrate as a minor end product when it was grown in the presence of yeast extract. Studies of the enzymology of the metabolic pathways of these strains (8) showed that glucose was fermented via the Embden-Meyerhof-Parnas pathway and involved a pyrophosphate-dependent phosphofructokinase (EC 2.7.1.90) rather than an ATP-dependent phosphofructokinase (EC 2.7.1.11). Strain Z-1203 ${ }^{\mathrm{T}}$ had a growth requirement for yeast extract which could be replaced by single amino acids, including L-alanine, L-glutamate, L-valine, and L-isovaline.

Cultural characteristics. Growth of both strains was inhibited by penicillin, neomycin, erythromycin, tetracycline, polymyxin $B$, and novobiocin at concentrations of 100 $\mu \mathrm{g} / \mathrm{ml}$. Rifampin and streptomycin at concentrations of 100 $\mu \mathrm{g} / \mathrm{ml}$ were not inhibitory to either strain. The differences in the temperature and $\mathrm{NaCl}$ ranges shown in Table 1 may reflect the conditions that prevailed at the sites of isolation. The isolation of similar strains from both a marine spring and a brackish thermal spring would encourage the search for

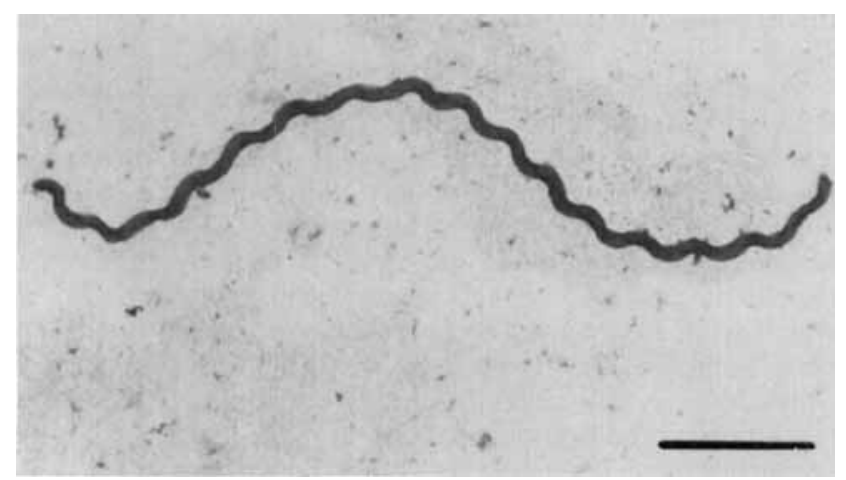

FIG. 1. S. thermophila. Negatively stained preparation showing helical cell morphology with regular coiling. Bar $=2.0 \mu \mathrm{m}$. further strains from freshwater thermal springs. The strains of Patel et al. (9) did not grow at temperatures above $60^{\circ} \mathrm{C}$, while our isolates grew at temperatures up to $73^{\circ} \mathrm{C}$.

Taxonomic position. The morphology of strains RI 19.B1 and $\mathrm{Z}-1203^{\mathrm{T}}$, together with their free-living nature and obligately anaerobic metabolism, places them in the genus Spirochaeta. These organisms differ from previously described strains in their extremely thermophilic and polysaccharolytic nature. None of the previously described members of the genus Spirochaeta grow at temperatures above $60^{\circ} \mathrm{C}$, and none have been shown to be polysaccharolytic.

The glucose fermentation end products differ from those of the previously described species, most of which produce ethanol as a major end product (the single exception is Spirochaeta zuelzerae, which does not produce ethanol but produces succinate [3]). Strains RI 19.B1 and Z-1203 ${ }^{\mathrm{T}}$ do not produce either ethanol or succinate from the fermentation of glucose. The trace of isobutyrate produced by strain $\mathrm{Z}-1203^{\mathrm{T}}$ has been shown to be a product of growth in the presence of yeast extract. Isobutyrate production has been demonstrated in the marine mesophilic spirochete Spirochaeta isovalerica (7).

The differences between strains RI 19.B1 and Z-1203 ${ }^{\mathrm{T}}$ and the previously described members of the genus Spirochaeta (3) are great enough to warrant a new species. We propose a new species, Spirochaeta thermophila, for our isolates, with strain Z-1203 (= DSM 6578) as the type strain.

Spirochaeta thermophila sp. nov. Spirochaeta thermophila (ther.mo' phi.la. Gr. n. therme, heat; Gr. adj. phila, loving; M. L. adj. thermophila, heat-loving). Single helical cells are 0.2 to 0.25 by 16 to $50 \mu \mathrm{m}$. Negative Gram stain reaction. No lysis of the cells occurs in $3 \% \mathrm{KOH}$. An outer sheath encloses a protoplasmic cylinder; two periplasmic flagella are present in a 1-2-1 arrangement and are subterminally anchored by an insertion disc. Strictly anaerobic chemoorganotroph. The temperature range for the type strain is $\mathbf{4 0}$ to $73^{\circ} \mathrm{C}$ (optimum, 66 to $68^{\circ} \mathrm{C}$ ). The $\mathrm{pH}$ range for the type strain is 5.9 to 7.7 (optimum, 7.5). The $\mathrm{NaCl}$ concentration range for the type strain is 0.5 to $4.5 \%$ (optimum, 1.5\%) (doubling time, $70 \mathrm{~min}$ ). The temperature, $\mathrm{pH}$, and salinity parameters vary for different strains, reflecting the environmental conditions prevailing at the sites of isolation. No reduction of fumarate, nitrate, oxygen, sulfate, or sulfur occurs. Utilizes various mono-, di-, and polysaccharides but not sugar alcohols, organic acids, or amino acids. Inhibited by penicillin, neomycin, erythromycin, tetracycline, polymyxin $B$, and novobiocin but resistant to rifampin and streptomycin. The fermentation end products from glucose are acetate, carbon dioxide, hydrogen, and lactate. Glucose is fermented via the Embden-Meyerhof-Parnas pathway, involving a pyrophosphate-dependent phosphofructokinase. Ethanol and succinate are not produced. Indole is not formed; urea is not hydrolyzed. Sulfide is not produced from cysteine, and 
esculin is hydrolyzed. The guanine-plus-cytosine content of the DNA is 52 mol\% (as determined by the thermal denaturation method). Type strain Z-1203 (= DSM 6578) was isolated from a marine hot spring near the beach on Shiashkotan Island, Soviet Far East, USSR.

\section{ACKNOWLEDGMENTS}

We thank N. Chernykh for his help with the DNA homology data. F.A.R. and P.H.J. were funded by Pacific Enzymes Ltd. F.A.R. thanks the Institute of Microbiology, USSR Academy of Sciences, Moscow, USSR, for hosting his visit in December 1990.

\section{REFERENCES}

1. Breznak, J. A., and E. Canale-Parola. 1975. Morphology and physiology of Spirochaeta aurantia strains isolated from aquatic habitats. Arch. Microbiol. 105:1-12.

2. Canale-Parola, E. 1981. Free-living anaerobic and facultatively anaerobic spirochetes: the genus Spirochaeta, p. 538-547. In M. P. Starr, H. Stolp, H. G. Truper, A. Balows, and H. G. Schlegel (ed.), The prokaryotes. A handbook on habitats, isolation and identification of bacteria, vol. 1. Springer-Verlag, New York.

3. Canale-Parola, E. 1984. The spirochetes, p. 38-46. In N. R. Krieg and J. G. Holt (ed.), Bergey's manual of systematic bacteriology, vol. 1. The Williams \& Wilkins Co., Baltimore.

4. DeLey, J., H. Cattoir, and A. Reynaerts. 1971. The quantitative measurement of DNA hybridization from renaturation rates. Eur. J. Biochem. 12:133-142.

5. Fracek, S. P., and J. F. Stolz. 1985. Spirochaeta bajacaliforniensis $\mathrm{sp}$. $\mathrm{n}$. from a microbial mat community at Laguna Figueroa, Baja, California Norte, Mexico. Arch. Microbiol. 142:317-325.

6. Greenberg, E. P., and E. Canale-Parole. 1976. Spirochaeto halophila sp. n., a facultative anaerobe from a high salinity pond. Arch. Microbiol. 110:185-194.

7. Harwood, C. S., and Canale-Parola. 1983. Spirochaeta isovalerica sp. nov., a marine anaerobe that forms branched-chain fatty acids as fermentation products. Int. J. Syst. Bacteriol. 33:573579.

8. Janssen, P. H. Unpublished data.

9. Patel, B. K. C., H. W. Morgan, and R. M. Daniel. 1985. Thermophilic anaerobic spirochetes in the New Zealand hot springs. FEMS Microbiol. Lett. 26:101-106.

10. Rainey, F. A., P. H. Janssen, D. J. C. Wild, and H. W. Morgan 1991. Isolation and characterization of an obligately anaerobic, polysaccharolytic, extremely thermophilic member of the genus Spirochaeta. Arch. Microbiol. 155:396-401.

11. Svetlichny, V., H. Aksenova, and G. Zavarzin. 1990. Extremely thermophilic cellulolytic anaerobes from hot springs of the Soviet Far East. Poster Abstract, Thermophily Today, International Meeting on Cell Constituents, Genetics and Biotechnological Applications of Thermophilic Microorganisms, Viterbo, Italy. 